\title{
Izabela Bukalska
}

Uniwersytet Kardynała Stefana Wyszyńskiego w Warszawie

Marek Gorzko

Akademia Pomorska w Słupsku

\section{Od redaktorów: Metodologia teorii ugruntowanej - współczesne inspiracje, spory i powroty}

DOI: http://dx.doi.org/10.18778/1733-8069.15.3.01

\begin{abstract}
Abstrakt Od momentu ukazania się publikacji B. Glasera i A. L. Straussa zasady ich metodologii wykorzystano w setkach projektów badawczych, przetestowano w rozmaitych sytuacjach w terenie. Prowadzona wśród praktyków ożywiona debata ujawniła rozmaitość ich światopoglądów i założeń leżących u podstaw badawczych przedsięwzięć. Między innymi te czynniki doprowadziły do wyłonienia się różnych odmian metodologii teorii ugruntowanej. Dziś, pół wieku od momentu opublikowania dzieła, osoby rozpoczynające przygodę z MTU mogą i muszą podjąć świadomą decyzję preferowanego kierunku. Niewątpliwą zaletą tej sytuacji jest to, że wiele dylematów terenowych zostało już wyartykułowanych w literaturze i nie trzeba się z nimi mierzyć samotnie w terenie. Bogactwo i zróżnicowanie dotyczy także obszarów rzeczowych - przydatność MTU jest odkrywana wśród badaczy rozmaitych proweniencji. Najwyraźniej zainteresowanie metodologią nie słabnie; przekazywany do rąk Czytelników tom prezentuje niektóre przedmioty debaty żywotne wśród badaczy inspirujących się wspomnianą perspektywą.
\end{abstract}

Słowa kluczowe metodologia teorii ugruntowanej, Anselm L. Strauss, Barney Glaser

Izabela Bukalska, dr, adiunkt w Katedrze Socjologii Kultury Uniwersytetu Kardynała Stefana Wyszyńskiego w Warszawie. Członkini Sekcji Socjologii Jakościowej i Symbolicznego Interakcjonizmu PTS. Autorka m.in. monografii Węgierskie mniejszości narodowe i ich światy społeczne (Wyd. UKSW, 2017). Zainteresowania obejmują tematykę mniejszości narodowych, badania nad etnicznością oraz różne aspekty uczestnictwa w kulturze. W badaniach wykorzystuje zasady metodologii teorii ugruntowanej.

\section{Adres kontaktowy:}

Katedra Socjologii Kultury, Instytut Socjologii UKSW

ul. Wóycickiego 1/3, 01-938 Warszawa

e-mail: i.bukalska@gmail.com
Marek Gorzko, dr hab., profesor nadzwyczajny w Zakładzie Socjologii Akademii Pomorskiej w Słupsku. Członek Zespołu Redakcyjnego „Przeglądu Socjologii Jakościowej”. Członek Sekcji Socjologii Jakościowej i Symbolicznego Interakcjonizmu Polskiego Towarzystwa Socjologicznego. Główne obszary zainteresowań badawczych to: socjologia jakościowa, problemy metodologiczne badań jakościowych, teoria ugruntowana, metoda biograficzna, socjologia pracy.

\section{Adres kontaktowy:}

Akademia Pomorska w Słupsku, Zakład Socjologii

ul. Bohaterów Westerplatte 64, 76-200 Słupsk

e-mail: marek.gorzko@gmail.com 
$\mathrm{P}$ ięćdziesiąta rocznica wydania Odkrywania teorii ugruntowanej Anselma L. Straussa i Barneya Glasera skłania do podsumowań i analizy przemian, jakie metodologia badań jakościowych przeszła od momentu wydania tej seminalnej publikacji. W Europie i na świecie zorganizowano w związku z tym kilka wydarzeń oraz wydano parę książek; spośród konferencji warto wymienić: „Metodologie jakościowe - stan badań pół wieku po Odkrywaniu teorii ugruntowanej” w Ustce (8 grudnia 2017 r.), „Wie weiter mit Anselm Strauss? Ein Ausblick nach 100 Jahren" (dotyczące też 50. rocznicy publikacji; Uniwersytet w Magdeburgu, 16-17 marca 2017 r.) czy sesja 9. Międzynarodowej Konferencji Metodologii Nauk Społecznych pt. „Five Decades of Grounded Theory Methodology: Feats, Fears, and Futurities" (Leicester, 11-16 września 2016 r.). Z publikacji wart uwagi jest chociażby jubileuszowy numer "Grounded Theory Review" - periodyku wydawanego przez środowisko skupione wokół Barneya Glasera.

Od 1967 roku wyodrębniło się wiele różnych podejść do zasad i procedur MTU. W innych kierunkach podążyli sami jej twórcy - A. Strauss i B. Glaser; Kathy Charmaz wypracowała w jej ramach podejście konstruktywistyczne (2006), a także zaproponowała podejście etnografii teorii ugruntowanej (2006); Adele Clarke ulokowała teorię ugruntowaną w paradygmacie postmodernistycznym (2005). Michelle Redman-MacLaren i Jane Mills (2015) uformowały podejście transformatywnej teorii ugruntowanej (transformational) oparte na krytycznym realizmie i odnoszące się do procedur participatory action research; Krzysztof Konecki (2011) rozciągnął procedury MTU na aspekt wizualny badań, tworząc zasady wizualnej teorii ugruntowanej. Obecnie w książce Advances in
Contemplative Research autor prezentuje perspektywę kontemplatywną. W 2017 roku Judith Holton i Isabelle Walsh opublikowały książkę Classic Grounded Theory: Applications with Qualitative and Quantitative Data, która jest ponownym zaznaczeniem stanowiska klasycznej MTU i głosem przedstawicielek perspektywy glaserowskiej wobec obserwowanego zróżnicowania perspektyw w polu MTU.

Wszystkie one jednak w taki czy inny sposób odnoszą się do Odkrywania teorii ugruntowanej. Istnienie takiego punktu odniesienia, pewnego kanonu tekstów, którego istotnym składnikiem jest właśnie ta praca, należąca między innymi do pewnej tradycji teoretycznej, nadają tym działaniom pewną jednolitość. Nie jest to chyba nawet bardzo swobodnie rozumiany paradygmat w sensie Thomasa S. Kuhna - gdzie bowiem łamigłówki, które chętnie rozwiązywaliby adepci tejże metodologii? Dziesięć lat temu Anthony Bryant i Kathy Charmaz w swoim wprowadzeniu do także "rocznicowego" The Sage Handbook of Grouded Theory (2007a: 11) zasugerowali, że mamy w tym przypadku do czynienia z "rodziną metod”, nawiązując do Wittgensteinowskiej koncepcji „podobieństwa rodzinnego", opartego na ocenie niepodatnej na jasne i precyzyjne definicje w klasycznym stylu.

Znaczną różnorodność można zaobserwować w przypadku obszarów badawczych, w jakich stosowane są procedury MTU - według bazy Web of Science 15231 artykułów odwołujących się do tej metodologii umiejscowionych jest w 130 takich obszarach (przede wszystkim pielęgniarstwo, psychologia, nauki o edukacji, środowisko publiczne ochrony zdrowia, zarządzanie, nauki informatyczne [computer science], ekonomia biznesowa [business economy] i wiele innych). 
Niniejszy numer skupia pewne aktualne wątki w refleksji nad metodologia. Wyłaniały i klarowały się one przez dziesięciolecia od pierwszego wydania The Discovery of Grounded Theory. Trafnie podsumowuja je Norman K. Denzin i Yvonna S. Lincoln, wyodrębniając dziewięć kolejnych faz rozwoju badań jakościowych z uwagi na typowe dla nich dylematy. Piszą o kryzysie reprezentacji, gdzie w watpliwość podawany jest autorytet badacza i jego uprawnienia do dokonywania ostatecznych podsumowań i interpretacji zebranych danych. Kryzys legitymizacji dotyczy zasadności kryteriów oceny badań jakościowych. Kryzys praktyki oznacza wątpliwość, że tekstualne analizy społeczeństwa są w stanie wywołać zmianę społeczną. Te aspekty znajdują odzwierciedlenie w tematyce artykułów.

Andrea Salvini w tekście The Methodological Convergences between Symbolic Interactionism and Constructivist Grounded Theory odnosi się do dawnego dylematu - relacji między konstruktywistyczną MTU a symbolicznym interakcjonizmem. Autor wyodrębnia zachodzące na siebie obszary i leksykon słownictwa wspólny dla obu perspektyw. To uporządkowanie jest przydatne z osób inspirowanych przez te dwa kierunki.

Krzysztof T. Konecki, w artykule Kreatywność w badaniach jakościowych. Pomiędzy procedurami a intuicją opisuje techniki pozwalające badaczowi na głębsze wejście w „kontekst odkrycia”, stymulację kreatywności przy tworzeniu nowych kategorii i pojęć oraz dostrzeganiu przez badacza nowych powiązań w danych. Tekst napisany w duchu konstruktywistycznym dąży jednak do sprawnego i adekwatnego uchwycenia cech badanej rzeczywistości ze strony umysłu poznającego. Odpowiada też na kwestię legitymizacji - autor mówi o trafnym nazywaniu kategorii, odnosząc się tym samym do kryteriów oceny.
Dominika Byczkowska-Owczarek w tekście The Analytical Procedures of Grounded Theory Methodology in Research on Human Body odnosi strategie MTU do nowego obszaru badawczego, jakim jest socjologia ciała. Autorka zauważa, że ciało jako zjawisko niemożliwe do doświadczania i odbierania przez innych oraz niekomunikowalne intersubiektywnie powinno być badane z perspektywy jego doświadczania i konstruowania przez samą jednostkę.

Marcin Frybes w analizie Sociological Intervention "a la polonaise": Alain Touraine's Method in the Polish Context przybliża historię wykorzystania badań interwencjonizmu socjologicznego na gruncie polskim. Perspektywa Alaina Touraine, wyrosła z tej samej rewolucji co MTU, nie uznaje autorytetu i reprezentatywności perspektywy badającego. Dodatkowo odpowiada na wspomniany kryzys praktyki, dostarczając wyjaśnień i wstępnych rozwiązań konkretnych sytuacji, $\mathrm{w}$ jakich znajdują się ruchy społeczne.

Artykuł Izabeli Bukalskiej Recepcja metodologii teorii ugruntowanej wśród polskich badaczy - refleksje 50 lat po publikacji B. Glasera i A. L. Straussa, na podstawie rozmów z trojgiem badaczy wstępnie opisuje okoliczności i przebieg przyjmowania perspektywy MTU na gruncie polskim.

Minęło pół wieku od publikacji Odkrywania... Czytelnik tej pracy ciągle jeszcze może uchwycić szczególny ton entuzjazmu i ekscytacji obecny w wywodach jej autorów. Emocje takie zdają się także towarzyszyć współczesnym badaczom zapoznającym się z nakreśloną w Odkrywaniu... strategią metodologiczną. Choć jej realizacja okazuje się w praktyce sprawą wcale nie taką łatwą, zachowuje ona jednak żywotność. 


\title{
Bibliografia
}

Bryant Anthony, Charmaz Kathy (2007) The Sage Handbook of Grouded Theory. London: SAGE Publications.

Charmaz Kathy (2006) Constructing Grounded Theory. Practical Guide Through Qualitative Analysis, London: Sage.

Clarke Adele (2005) Situational Analysis: Grounded Theory After the Postmodern Turn. London: Sage Publications.

Glaser Barney, Strauss Anselm L. (2009) Odkrywanie teorii ugruntowanej. Strategie badania jakościowego. Kraków: Nomos.
Holton Judith, Walsh Isabelle (2017) Classic Grounded Theory: Applications with Qualitative and Quantitative Data. Los Angeles: Sage.

Konecki Krzysztof (2012) Wizualna teoria ugruntowana: podstawowe zasady i procedury, „Przegląd Socjologii Jakościowej” t. 8, nr 1, s. 12-45.

Konecki Krzysztof (2018) Advances in Contemplative Research. Łódź, Kraków: Wydawnictwo Uniwersytetu Łódzkiego/Jagiellonian University Press.

Redman-MacLaren M., Mills J. (2015) Transformational Grounded Theory: Theory, Voice, and Action, „International Journal of Qualitative Methods", vol. 14, no. 3, s. 1-12.

\section{Cytowanie}

Bukalska Izabela, Gorzko Marek (2019) Od redaktorów: Metodologia teorii ugruntowanej - współczesne inspiracje, spory i powroty. „Przegląd Socjologii Jakościowej”, t. 15, nr 3, s. 6-9 [dostęp dzień, miesiąc, rok]. Dostępny w Internecie: «www.przegladsocjologiijakosciowej.org>. DOI: http://dx.doi.org/10.18778/1733-8069.15.3.01.

\section{Editorial: Grounded Theory Methodology: Contemporary Inspirations, Disputes, and Returns}

\begin{abstract}
Since the publication of Barney Glaser and Anselm L. Strauss' major work, the principles of the authors' methodology have been used in hundreds of research projects and tested in various field situations. A lively debate taking place among practitioners has revealed a variety of their worldviews, stances, and assumptions that underlie research ventures. It is these factors among other things that led to the emergence of different variants of grounded theory methodology. Today, half a century after the publication of the said work, people beginning their adventure with GTM can - and should - make an informed decision as to the type of GTM that they prefer to use. One obvious advantage of this situation is the fact that many field dilemmas have already been articulated in the source literature, which is why one does not have to confront them in the field on their own. The richness and diversity also applies to substantive areas; the usefulness of GTM is being discovered by researchers of various backgrounds and provenances. Apparently, general interest in methodology is not waning. The volume herein presents some of the questions and matters that are the subject of animated discussions among those researchers who are inspired by the aforementioned perspective.
\end{abstract}

Keywords: grounded theory methodology, Anselm L. Strauss, Barney Glaser 